International Research Journal of Management, IT \& Social Sciences
Available online at https://sloap.org/journals/index.php/irjmis/
Vol. 6 No. 4, July 2019, pages: 207 213
ISSN: 2395-7492
https://doi.org/10.21744/irjmis.v6n4.683

\title{
Effect of Taxation Modernization on Tax Compliance
}

\author{
I Nyoman Wirya Sentanu ${ }^{a}$ \\ Ketut Budiartha ${ }^{b}$
}

\section{Article history:}

Received: 27 March 2019

Accepted: 31 May 2019

Published: 31 July 2019

\section{Keywords:}

administrative;

e-billing;

e-filing;

fine sanctions;

tax compliance;

\begin{abstract}
This study aims to examine the effect of using e-filing, the use of e-billing and administrative fines on individual taxpayer compliance in Badung Regency. Non-compliance with taxpayers can lead to reduced tax potential that can be netted. The transition to a technology-based tax reporting system is expected to help improve tax compliance. The method of data collection in this study is a survey method with questionnaire techniques. The population in this study was 126,477 taxpayers and the sample in this study were 100 taxpayers registered at North Badung KPP and South Badung KPP. The variable use of e-filing is measured by perceptions of usability and perceptions of ease of use. Variables for using e-billing are measured by perceptions of usability and ease of use. Administrative penalty variables are measured by four indicators, namely the function of tax sanctions, sanctions for tax violations, sanctions according to the level of violations and the application of sanctions according to regulations. The analysis technique used is multiple linear regression analysis. The results of the study show that e-filing has a positive effect on taxpayer compliance, e-billing has a positive effect on taxpayer compliance and administrative fines have a positive effect on taxpayer compliance.
\end{abstract}

2395-7492@ Copyright 2019. The Author. This is an open-access article under the CC BY-SA license (https://creativecommons.org/licenses/by-sa/4.0/) All rights reserved.

\footnotetext{
Author correspondence:

I Nyoman Wirya Sentanu,

Faculty of Economics and Business,

Udayana University, Denpasar, Bali, Indonesia.

Email address: wiryasentanu@gmail.com
}

\section{Introduction}

Improving taxpayer compliance means the same as encouraging taxpayer awareness itself. Directorate General of Taxes (DGT) is an institution that carries the task of securing state revenues and is required to be able to meet the tax revenue target (Palupi, 2010). DGT in an effort to meet the given target seeks to utilize the development of technology and information (information technology) in order to facilitate, improve and optimize services to taxpayers by simplifying the procedures for reporting SPT both SPT Period and Annual SPT (Pioner, 2018).

\footnotetext{
a Faculty of Economics and Business, Udayana University, Denpasar, Indonesia ${ }^{\mathrm{b}}$ Faculty of Economics and Business, Udayana University, Denpasar, Indonesia
} 
Modernization of tax services is the administration of tax services through the use of information and communication technology with the aim of facilitating the SPT reporting method. Of course, tax administration is no longer relevant using manual methods to get optimal results in this digital era. This moderation is important so that taxpayers feel the ease in complying with their tax obligations. One of the causes of the lack of taxpayer compliance is a difficult, ineffective, and inefficient administration process that creates a small number of compliance costs.

Attribution theory states that a person's behavior is determined by a combination of internal forces (internal forces) which are factors that originate from within a person such as ability or effort and external strength, such as difficulty in assignments or luck (Suartana, 2010; Pandey, 2017; Lisa, 2018). Based on this, someone is motivated to understand the environment and the causes of certain events. Based on this theory, the compliance of taxpayers can be influenced by internal factors and external factors of the taxpayer.

In realizing the tax modernization above, DGT made a breakthrough by launching an electronic reporting system called the Electronic Filing System (e-filing). E-filing is an electronic service delivery or delivery service for individuals and agencies to the DGT through an Application Service Provider (ASP) by utilizing online and real-time internet communication channels, so that taxpayers no longer need to do so. Printing all report forms and waiting for the receipt manually (Karmila, 2016). The purpose of e-filling is to improve services by facilitating SPT reporting electronically to taxpayers without having to queue at the Tax Office and speed up the transaction process because data is sent directly to the database of the Directorate General of Taxes.

The transition of online tax reporting actually began in 2005 but the number of taxpayers who use e-filing systems is very small as well as the growth of its users. In practice, this system is not an easy thing to do. The e-filing system offers benefits to taxpayers, but the benefits obtained are still hindered by the reluctance of users to accept and use available electronic services (Obid et al., 2004; Wiguna \& Yadnyana, 2019; Aksiana \& Sujana, 2019). Individuals who are not familiar with and understand the level of technological readiness have a lower intention to use technologybased products and services.

In addition to the electronic reporting system, DGT also launched an electronic payment system. The e-billing system was created to support the current tax collection system (self-assessment system) so that taxpayers can make tax payments independently and still uphold honesty in reporting taxes. The use of information technology in modernizing e-system-based systems is expected to increase compliance and trust in tax administration. The purpose of providing online services is also intended that taxpayers not be late in fulfilling their obligations.

Delays in reporting and paying taxes will have an impact on the level of compliance and the emergence of sanctions for the delay. Sanctions given can be in the form of administrative sanctions up to criminal sanctions. Provision of sanctions by issuing Tax Bill (STP) to individual taxpayers is one of the ways the government provides a deterrent effect on taxpayers. Behind this, the provision of STP and tax audits to individual taxpayers tends to increase.

\section{Literature Review and Hypothesis}

Individual behavior in attribution theory is determined by internal factors such as ability and effort and external factors such as difficulties. Taxpayers in using technology-based systems from DGT to report their tax obligations must be able to operate computers or internet-based technology. In an effort to improve taxpayer compliance, DGT made a breakthrough to require taxpayers to use e-filing and e-billing in fulfilling their tax obligations. External factors that can affect taxpayer compliance are administrative penalties imposed by the government. The granting of administrative fines can provide a deterrent effect on taxpayers who do not report their tax obligations.

\section{The Effect of e-filing on the Compliance of Individual Taxpayers in Badung Regency}

E-filing is a method of submitting periodical SPT or annual SPT by an individual or entity to DGT that is conducted online and in real-time. The transfer of tax reporting from manual to e-filing is a breakthrough in providing services to the public. It is expected that with the e-filing system, taxpayers remember their tax obligations because with this system the tax magic no longer has to queue at the tax office but can report their SPT from anywhere and anytime. Novarina (2005), that the e-filing system proved to be fast, accurate, efficient and effective because taxpayers can directly submit their Notification online without having to go to the tax service office and will receive confirmation of reports that have been submitted, immediately upon receipt (real-time). Husnurrosyidah (2017), the research examines the effect of e-filing, e-Billing, and e-Invoice on Tax Compliance with BMT in Kudus District. The results showed that e-filing had an effect on compliance, e-billing had an effect on compliance and e-invoicing had an effect on compliance. Based on the theory and several studies above, the hypothesis can be formulated as follows: 
H1: e-filing has a positive effect on individual taxpayer compliance in Badung Regency.

\section{The Effect of e-billing on the Compliance of Individual Taxpayers in Badung Regency}

The transition from the Tax Payment Letter (SSP) to e-billing is intended so that tax obligations can remain fulfilled and without constraints, and avoid taxation sanctions if they do not fulfill their tax obligations in accordance with applicable regulations. Services based on e-billing can make it easier for users to transact anywhere and anytime. This convenience will obviously help taxpayers because there is no need to wait at the bank in paying taxes and. In addition, e-billing can also be paid outside the operating hours of tax offices and banks. It is expected that with this breakthrough the level of tax compliance will increase. Husnurrosyidah (2017), the research examines the effect of e-filing, e-Billing, and e-Invoice on Tax Compliance with BMT in Kudus District. The results of this study indicate that e-filing has an effect on compliance, e-billing has an effect on compliance and e-invoicing influences compliance. Handyani (2017), examines the Effects of E-billing System Implementation on Taxpayer Compliance in KPP Pratama, Padeglang Regency. The results showed that the application of e-billing systems had a positive and significant effect on taxpayer compliance. Based on the theory and several studies above, the hypothesis can be formulated as follows:

H2: e-billing has a positive effect on individual taxpayer compliance in Badung Regency

\section{The Effect of Administrative Fines Sanctions on the Compliance of Individual Taxpayers in Badung Regency}

Law Number 28 of 2007 Article 7 concerning General Provisions and Procedures for Taxation, sanctions are acts in the form of penalties given to people who violate the rules. If the sanctions imposed on taxpayers are increasingly not fulfilling their obligations, it will affect the increase in tax compliance. Taxpayers will fulfill their tax obligations if they view tax sanctions as damaging to them. According to Jayusman (2017), tax sanctions have a positive and significant effect on individual taxpayer compliance. Sicily (2016), states that the implementation of administrative sanctions, tax authorities services, knowledge and understanding of tax regulations and awareness has a positive and significant effect on tax compliance. Based on the theory and several studies above, the hypothesis can be formulated as follows:

H3: Administrative Fines Sanctions have a positive effect on the Compliance of Individual Taxpayers in Badung Regency

\section{Materials and Methods}

This research was conducted at the Pratama Tax Service Office (KPP) in North Badung and South Badung Primary Tax Office. The location of this study was chosen because of the low percentage of individual taxpayer compliance in the two KPPs which allowed for non-compliance. This research was conducted in 2017.

The population in this study were all individual taxpayers registered in Badung Regency in 2017 which were 126,477 individual taxpayers. Determination of the number of samples for each KPP is determined proportionally so that each KPP is represented, the number of samples used in this study amounts to 100 taxpayers who are calculated using the Slovin formula.

The analysis technique in this study will use multiple regression equations to see the dependency relationship between the dependent and free variables. Multiple linear regression analysis is used to determine the effect that occurs between the variables e-filing, e-billing, and administrative penalties on taxpayer compliance as the dependent variable.

\section{Results and Discussions}

\section{Multiple Linear Regression Test}

To find out the effect of e-filling, e-billing and Administrative Fines Sanctions on Taxpayer Compliance, multiple linear regression analysis is used because more than one independent variable is used. The following are the results of multiple linear regression analysis in Table 1.

Sentanu, I. N. W., \& Budiartha, K. (2019). Effect of taxation modernization on tax compliance. International Research Journal of Management, IT and Social Sciences, 6(4), 207-213. https://doi.org/10.21744/irjmis.v6n4.683 
Table 1

Regression Analysis

\begin{tabular}{|c|c|c|c|c|c|}
\hline \multirow[t]{2}{*}{ Model } & \multicolumn{2}{|c|}{$\begin{array}{c}\text { Unstandardized } \\
\text { Coefficients }\end{array}$} & \multirow{2}{*}{$\begin{array}{c}\begin{array}{c}\text { Standardized } \\
\text { Coefficients }\end{array} \\
\text { Beta }\end{array}$} & \multirow[t]{2}{*}{$\mathrm{t}$} & \multirow[t]{2}{*}{ Sig. } \\
\hline & $\beta$ & Std. Error & & & \\
\hline (Constant) & 0,180 & 0,677 & 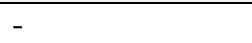 & 0,265 & 0,791 \\
\hline$e$-Filling $\left(\mathrm{X}_{1}\right)$ & 0,157 & 0,033 & 0,346 & 4,772 & 0,000 \\
\hline$e$-Billing $\left(\mathrm{X}_{2}\right)$ & 0,180 & 0,038 & 0,349 & 4,741 & 0,000 \\
\hline Fine $\left(X_{3}\right)$ & 0,305 & 0,069 & 0,300 & 4,401 & 0,000 \\
\hline $\mathrm{R}$ & & & 0,897 & & \\
\hline $\mathrm{R}^{2}$ & & & 0,804 & & \\
\hline Adjusted $\mathrm{R}^{2}$ & & & 0,798 & & \\
\hline$F_{\text {count }}$ & & & 131,127 & & \\
\hline Significance F & & & 0,000 & & \\
\hline
\end{tabular}

Data Sekunder, 2019

Based on Table 1, the regression equation can be arranged as follows:

$$
\mathrm{Y}=0,180+0,157 \mathrm{X}_{1}+0,180 \mathrm{X}_{2}+0,305 \mathrm{X}_{3}
$$

F Test

The feasibility test model (F Test) was conducted to determine whether the model used in this study is a fit model (a decent model) by looking at the calculated $\mathrm{F}$ value and its significance level. This test is carried out before testing the hypothesis. Based on Table 5.9, it is known that F count is 131.127 with a significance level of 0.000 smaller than $a=0.05$, so this research model is feasible to be used to prove the hypothesis formed or in other words a model fit.

\section{Regression Coefficient Test (t-Test)}

The t-test is used to find out whether there is an influence of the independent variable on the dependent variable. If the significance value is $<0.05$, then the independent variable has an effect on the dependent variable. The test results are partially as follows:

1) Based on Table 1, the value of $t$ count for the e-filling variable is 4.772 with a significance level of 0.000 , which is less than 0.05 and has a positive regression coefficient of 0.157 . This means that e-filing has a positive effect on individual taxpayer compliance in Badung Regency, so Hypothesis 1 is accepted and Hypothesis 0 is rejected.

2) Based on Table 1, the value of t count for the e-billing variable is 4.741 with a significance level of 0.000 , which is less than 0.05 and has a positive regression coefficient of 0.180 . This means that e-billing has a positive effect on individual taxpayer compliance in Badung Regency, so Hypothesis 2 is accepted and Hypothesis 0 is rejected.

3) Explanation in Table 1, that the value of $t$ arithmetic for administrative penalties variable is 4,401 with a significance level of 0,000 , which is less than 0,05 and has a positive regression coefficient of 0,305 . This means that administrative penalties have a positive effect on individual taxpayer compliance in Badung Regency, so Hypothesis 3 is accepted and Hypothesis 0 is rejected.

\section{The Effect of e-filing (X1) on Compliance with Individual Taxpayers in Badung Regency (Y)}

An in-depth discussion is needed to give meaning or meaning to static values from hypothesis testing, namely the effect of e-filing (X1) on individual taxpayer compliance in Badung Regency. Based on the results of multiple linear regression analysis in Table 1, e-filing has a positive and significant effect on individual taxpayer compliance in Badung Regency. This is indicated by a significance value of 0,000 whose value is smaller than the specified significance level $(a=0.05)$ and has a coefficient of 0.157 , so $\mathrm{H} 1$ is accepted ie e-filing has a positive effect on individual taxpayer compliance in Badung Regency. The results of the analysis support the hypothesis that the higher 
the use of e-filing, the higher the individual taxpayer compliance in Badung Regency, and vice versa, the lower the use of e-filing, the lower the individual taxpayer's compliance in Badung Regency.

\section{The Effect of e-billing (X2) on the Compliance of Individual Taxpayers in Badung Regency $(Y)$}

The discussion of testing the next hypothesis is the effect of using e-Billing (X2) on individual taxpayer compliance in Badung Regency. Based on the results of multiple linear regression analysis in Table 5.9 that the use of e-billing has a positive and significant effect on individual taxpayer compliance in Badung Regency. This is indicated by a significance value of 0,000 whose value is smaller than the specified significance level $(a=0.05)$ and has a coefficient of 0.180, so $\mathrm{H} 2$ is accepted, e-billing has a positive effect on individual taxpayer compliance in Badung Regency. This is in line with the research conducted by Pioner (2018) examining the Analysis of the Attitude of Taxpayers' Acceptance of the Use of E-billing Information Systems in Sleman Regency. Hadyani's research (2017) also concludes about the influence of the implementation of e-billing system will influence Taxpayer Compliance in KPP Pratama Padeglang Regency. This convenience will obviously help taxpayers because they do not need to wait at the bank in paying their taxes. In addition, e-billing is also paid in addition to the operating hours of tax offices and banks. It is expected that with this breakthrough the level of tax compliance will increase.

\section{The Effect of Administrative Fines Sanctions (X3) on Compliance with Individual Taxpayers in Badung Regency (Y)}

The discussion of the last hypothesis testing is the effect of using administrative fines (X3) on individual taxpayer compliance in Badung Regency. Based on the results of multiple linear regression analysis in Table 5.9 that the use of administrative fine sanctions has a positive and significant effect on individual taxpayer compliance in Badung Regency. This is indicated by a significance value of 0,000 whose value is smaller than the specified significance level $(a=0.05)$ and has a coefficient of 0.305 so that $\mathrm{H} 3$ is accepted ie administrative fine sanctions have a positive effect on individual taxpayer compliance in Badung Regency. This is in line with the research conducted by Jayusman (2017), where tax sanctions have a positive and significant effect on individual taxpayer compliance. Sicily (2016; Prena et al., 2019; Pattiasina et al., 2019), states that the implementation of administrative sanctions, tax authorities services, knowledge and understanding of tax regulations and awareness has a positive and significant effect on tax compliance. Even though they do not get an award for their compliance in carrying out tax obligations, taxpayers will be penalized if they deliberately do not pay their tax obligations.

\section{Conclusion}

The use of e-billing has a positive effect on the Compliance of Individual Taxpayers in Badung Regency. This result means that the better the application of e-filing, the more taxpayer compliance will be increased. In other words, the transfer of tax reporting from manual to e-filing is a breakthrough in terms of providing services to the public so that taxpayers at least remember their tax obligations because with this system taxpayers no longer have to queue at the Tax Office but can report their SPT from anywhere and anytime.

The use of e-billing has a positive effect on the Compliance of Individual Taxpayers in Badung Regency. Based on these results, the better use of e-billing, the more taxpayer compliance will be increased. In other words, with the application and understanding of the use of e-billing as a means of payment of taxes will provide comfort in the transaction by taxpayers. This system can also make payments using mobile banking because e-billing can issue its own tax payment code so that taxpayers do not have to wait at the bank in paying taxes. In addition, e-billing can also be paid in addition to the operating hours of tax offices and banks.

The application of Administrative Fines Sanctions has a positive effect on the Compliance of Individual Taxpayers in Badung Regency. Based on the results of this study, the better the Application of Administrative Fines Sanctions, the more taxpayer compliance increases. In other words, taxpayers will fulfill their tax obligations if they view tax sanctions as detrimental to them.

\section{Suggestion}

Viewed from the value of Adjusted R Square is 0.798, which means that 79.8 percent of the dependent variable is taxpayer compliance can be explained by the variables e-filling, e-billing and Tax Sanctions while the remaining 20.2

Sentanu, I. N. W., \& Budiartha, K. (2019). Effect of taxation modernization on tax compliance. International Research Journal of Management, IT and Social Sciences, 6(4), 207-213. https://doi.org/10.21744/irjmis.v6n4.683 
percent is influenced by other variables that are not included in this research model. Future research is expected to conduct research on all Tax Service Offices located in Bali as a comparison of taxpayer compliance. In addition, further research can add other variables related to taxpayer compliance such as financial statement variables. This is an opportunity for future researchers to develop this research in the future.

Conflict of interest statement and funding sources

The authors declared that they have no competing interest.

Statement of authorship

The authors have a responsibility for the conception and design of the study. The authors have approved the final article.

Acknowledgments

The authors would like to thank the Editor of IRJMIS for their valuable time, support, and advice in completing the current study. 


\section{References}

Akib, M., Sari, I. M., \& Asnia, A. (2017). Pengaruh Tanggung Jawab Moral Dan Kualitas Pelayanan Terhadap Kepatuhan Pelaporan Wajib Pajak Badan (Studi pada Kantor Pelayanan Pajak Pratama Kendari). Jurnal Akuntansi dan Keuangan, 2(2).

Aksiana, I. B. W., \& Sujana, I. K. (2019). Effect of Risk Preference, Professional Domination, Information, and Professional Relationship on Ethical Decision Making of Tax Consultants. International Research Journal of Management, IT and Social Sciences, 6(4), 174-179. https://doi.org/10.21744/irjmis.v6n4.675

Boissevain, J. (1966). Patronage in sicily. Man, 1(1), 18-33.

Handayani, P. W., Hidayanto, A. N., Pinem, A. A., Hapsari, I. C., Sandhyaduhita, P. I., \& Budi, I. (2017). Acceptance model of a hospital information system. International journal of medical informatics, 99, 11-28.

Husnurrosyidah, H. (2017). Pengaruh E-Filing, e-Billing dan e-Faktur Terhadap Kepatuhan Pajak pada BMT SeKabupaten Kudus. Jurnal Analisa Akuntansi dan Perpajakan, 1(1).

Jayusman, S. F. (2017). Faktor-Faktor Yang Mempengaruhi Kepatuhan Wajib Pajak Orang Pribadi Dengan Sosialisasi Perpajakan Sebagai Variabel Moderasi Pada Kantor Pelayanan Pajak Pratama Medan Polonia.

Karmila, M. (2016). Analisis Perhitungan, Pemotongan, Penyetoran, dan Pelaporan Pajak Penghasilan Pada PDAM Tirta Pakuan Kota Bogor. Skripsi. Universitas Pakuan.

Lisa, O., \& Hermanto, B. (2018). The effect of tax amnesty and taxpayer awareness to taxpayer compliance with financial condition as intervening variable. International Research Journal of Management, IT and Social Sciences, 5(2), 227-236.

Novarina, G. (2012). The territorial anchoring of the economy: from the industrial district to the metropolis. Political economy, (1), 16-25.

Obid, S. N. S. (2004). The influence of penalties on taxpayers'compliance: a comparison of the theoretical models. International Journal of Economics, Management and Accounting, 12(1).

Palupi, E. (2010). Pengaruh Penerapan Sistem Administrasi Perpajakan Modern terhadap Kepatuhan Wajib Pajak dan Penerimaan Pajak Penghasilan Orang Pribadi pada Kantor Pelayanan Pajak Pratama Jakarta Gambir Empat. Universitas Indonesia. Jakarta.

Pandey, M. (2017). Impact of goods and service tax (GST) on Indian tax structure. International Research Journal of Management, IT and Social Sciences, 4(3), 22-33.

Pattiasina, V., Tammubua, M. H., Numberi, A., Patiran, A., \& Temalagi, S. (2019). Capital Intensity and tax avoidance. International Journal of Social Sciences and Humanities, 3(1), 58-71. https://doi.org/10.29332/ijssh.v3n1.250

Pioner, H. (2018). Analisis sikap penerimaan wajib pajak terhadap penggunaan sistem informasi e-billing di Kabupaten Sleman.

Prena, G. D., Kustina, K. T., Dewi, I. G. A. A. O., Putra, I. G. C., \& Krisnanda, R. A. (2019). Tax sanctions, tax amnesty program, and tax obligation placement towards compliance report on corporate taxpayers. International Journal of Social Sciences and Humanities, 3(1), 26-35. https://doi.org/10.29332/ijssh.v3n1.249

Suartana, I. W. (2010). Akuntansi Keperilakuan Teori dan Implementasi. Andi. Yogyakarta.

Wiguna, I. P. I., \& Yadnyana, K. (2019). The role of working experience moderating the effect of emotional intelligence, intellectual intelligence, and spiritual intelligence on the ethical decision of tax consultants in Bali area. International Research Journal of Management, IT and Social Sciences, 6(3), 18-28. https://doi.org/10.21744/irjmis.v6n3.624

Sentanu, I. N. W., \& Budiartha, K. (2019). Effect of taxation modernization on tax compliance. International Research Journal of Management, IT and Social Sciences, 6(4), 207-213. https://doi.org/10.21744/irjmis.v6n4.683 